\title{
A Bridge to the Past: Public Memory and Nostalgia for the Communist Times in Modern Georgia
}

\section{Elisabeth Kovtiak}

\section{The Graduate School for Social Research}

\begin{abstract}
This paper deals with the politics of memory in contemporary Georgia's public space. It explores the relations between official and vernacular commemorations of the Soviet past in Tbilisi. In this paper, I have studied the forms of materialization of vernacular memories in the public space and provided a frame in which they exist, including the ideological background of decommunization in Georgia and peculiarities of the Soviet era museumizing in state museums. The official discourse demonizes the previous epoque and neglects all its benefits, whereas the ordinary people are quite nuanced in their memories of their past - this contradiction leads to manifestations of vernacular memories. Therefore, this paper focuses mostly on Tbilisi's Dry Bridge, a famous flea market where the memory of the recent Soviet past is negotiated. The main argument is that this particular flea market and its artifacts might be regarded as a "vernacular memorial" and "lieu de memoire" where nostalgia for an officially demonized era can be expressed and materialized. This paper explores the items that are on sale, explaining their meaning for the post-Soviet people, and describes the intangible practices that can be observed there. In addition, this paper unpacks that these nostalgic practices should not be considered as "unhealthy" or "retrospective" as it helps people to adapt to modernity and develop by considering more than one hegemonic version of their past.
\end{abstract}

\section{Keywords}

nostalgia; flea market; vernacular memorial; decommunization; public memory

To understand the specifics of collective memory and nostalgia for the communist times in today's Georgia, it is important to look back to the first two decades of country's sovereignty. Georgia obtained independence from the USSR in early 1991, and at that time, interethnic conflict in South Ossetia (1991-1992) already had been escalating. Soon after, a military conflict in Abkhazia had started and continued from August 1992 to September 1993. Although these conflicts sometimes are described as civil wars in the result of an ethnic conflict, the separatists had begotten the military aid from Russia

\footnotetext{
* Elisabeth Kovtiak, The Graduate School for Social Research, IFIS PAN, Staszic Palace, Nowy, Nowy Świat 72, 00-330 Warsaw, Poland; gssr@gssr.edu.pl.
} 
(Gachechiladze 1997). Till today, Abkhazia and South Ossetian territories are considered to be under Russian occupation.

Establishing power in a new independent was also not smooth. The first years of independence were marked by armed conflicts between the first president Zviad Gamsakhurdia, his supporters, and military forces of Georgia. Gamsakhurdia was forced to resign after being in office just for a few months - from April 1991 to January 1992 - after that, the Military Council became the interim head of state, until Eduard Shevardnadze was elected as a president in 1995 (Gachechiladze 1997, 56). The period of Shevardnadze's reign was marked by a high level of corruption, unstable situation in South Ossetia and Abkhazia, a growth of organized crime, and criminalization of the government. During this period, Georgian citizens experienced severe living conditions and extremely low income, deficiency of goods, and outages of electricity and water supply (Stefes 2006).

Shevardnadze was deposed in the result of the Rose Revolution that took place in 2003, and Mikheil Saakashvili came to power. The Rose Revolution aimed to improve the internal and external policies of Georgia, and most importantly, stop the corruption. As the revolution was pro-Western and had financial support from the United States Agency for International Development, it also declared a new course for the country's external affairs. The new course was West oriented, and the Georgian government tried to put an end to the economic dependence on Russia and to obliterate the country's Soviet past that was creating a cultural and historical bond with modern Russia. Moreover, in 2008, another military conflict occurred in South Ossetia, which led to sanctions and worsening of diplomatic relations between both countries (Tsygankov and Wahlquist 2009).

To reinforce political and cultural separation from Russia, Saakashvili's government enacted a law called Freedom Charter, which declared the use of Soviet symbols, such as the emblem of the USSR, the hammer and sickle, and red stars, illegal; all the country's monuments of Soviet leaders were also torn down (Freedom Charter 2011). It helped to create the main narrative and established a new, pro-Western course for Georgia's state development. However, it has also led to excluding a vast group from the narrative and created a split between older and younger, as memory and new reinterpreted history became competitive to each other (Shafir 2006). This has led to a controversy between vernacular and official memories.

Hence, Tbilisi's urban environment today barely reminds people of the recent Soviet past of the country. However, there are a significant percentage of Georgian citizens who share good memories about their Soviet past and retain 
a good attitude toward the USSR and Russia, in spite of all the adversities their country has faced within the last century.

The urban environment usually represents the public memory of the residents of this place. Public memory is a form of remembrance practiced by members of a certain community or by citizens of a certain country that entails what should be remembered or, on the contrary, obliterated and how it is framed in the public sphere. Public memory differs from recorded history, as it is more diverse in representations and has a higher level of informality and mutability (Houdek and Phillips 2002). According to Bodnar (1992), it includes two types of memory: official, which can be described as the commemorations expressed in institutionalized forms, and vernacular, which is recollections of those who witnessed the event itself.

Official memory represents a consistent and politicized version of the past, as it derives from authorities and political elites to serve their interests in supporting their ideology and constructing national identity. Vernacular memory is much more complex and ambiguous as it is shared by different social groups, making it more flexible and vivid. As it is located not in institutions but in people's recollection, it represents the events and how they were experienced by people, not how the authorities would like to interpret the past. Vernacular memories often become a basis for the formation of the official commemoration, but in some cases, these types of memories are controversial. Thus, they may create a tension between citizens and government or between different social groups that do not agree with the ways their past is perceived and materialized in memory formats.

Explanations of specifics of collective memory about the Soviet past in the post-communist countries vary depending on the relation to Russia. This is due to the fact that the Russian empire and the USSR can be considered as a colonizer, as countries of the Soviet bloc are related to them as colonies. Colonizers always attempt to erase social memory to enforce the power in their colonies (Kuzio 2002).

In order to build a factual independence, it is vital to reinterpret and reclaim the historical past. Therefore, after obtaining independence from the USSR, its constituent republics in the first place started to reconstruct narratives about their past and separate themselves from mythologies provided by the Soviet Union. Different countries had done this at different moments of time. For example, Latvia, Estonia, and Lithuania had done this almost immediately after the dissolution of the USSR, Belarus had not done this till today, and Ukraine (Shevel 2009) and Georgia have done this more than a decade after the dissolution of the USSR, when their political courses shifted. 
Post-communist countries became a Petri cup for studying collective memory and nostalgia, as the changes in political and social system happened quite recently and were dramatic enough to conceptualize nostalgia and analyze the variety of forms it may take. Majority of the research is dedicated to Eastern Germany, and its Ostalgie, ex-Yugoslavia's Yugonostalgia, and other Central European and Balkan countries. However, Georgia has its specific type of nostalgia that developed and existed in a completely different context. In Georgia, nostalgic feelings contradict the official narrative, help to cure the trauma and survive, and in a new economic situation, attracts tourists and creates agonism in public sphere.

There is no single theory that would explain causes of nostalgia alone. Some of these approaches explain the origins of nostalgia as a replenishment of a deficiency in ideology and meanings or sympathy to the failed utopia those bring to the creation of new political ideas and creating monuments, movies, and other cultural projects that help to reconnect with the past (social deficiency and failed utopia approaches). Another paradigm links nostalgia to the commercialization of the past, which is done through "re-exoticization" of the Soviet culture that helps to commodify the memory of the communist past, its peculiarities, and esthetics (Bartmanski 2011). Furthermore, Boym (2007, xv) had suggested meaning of post-communist nostalgia as "the heroic refusing to surrender to the irreversibility of time". Using this framework, I have addressed in this paper different modalities of nostalgia: cultural industry approach, commodification of nostalgia, childhood nostalgia, and nostalgia for the lost motherland. I have applied these approaches to analyze nostalgia's manifestations at Dry Bridge flea market.

The Dry Bridge flea market is a secondhand street trading place that can be also called a site of attraction for tourists and flaneurs. Apart from items from the Soviet past, such as banners, portraits, badges, porcelain figurines, cutlery and crockery, and vintage devices, one can also find modern souvenirs and paintings and new and used bijouterie in this market. This paper focuses on the part of the market where objects of Soviet life are on sale. I have analyzed them as a "vernacular memorial" and the place of manifestation of Soviet Union's legacy in the police's public space in a position to museums that transmit the official narrative.

In this paper, I have elaborated on the clash between the official memory and vernacular memory of the communist past in Tbilisi's public sphere and extricated how the vernacular memories appear in materialized forms when they are excluded from the official narrative of the past. This paper presents results of fieldwork that took place in July-August 2017 in Tbilisi and Gori. 
In the first part, I have carried out discourse analysis of museums' permanent exhibitions that are thematically connected to the Soviet Past: Museum of Soviet Occupation and National Art Museum, which are the parts of the National Museum of Georgia and Joseph Stalin Museum in Gori.

The second part of my research was a participant covert observation with a series of ethnographic interviews. A total of 15 interviews with vendors and visitors of the market were held to explore their personal attitudes to the market, motivations for the visit, and their opinions about the Soviet period. I contend that the public memory about the Soviet past in Georgia is fractured on many levels. The conflict of remembrance and reading of the recent history creates polarizations in the society and forces certain groups to search for a place in the society that would represent their attitude as they themselves and their memories had been excluded from the official narrative. This displacement brings nostalgic feelings. In this article, I have stated that the Dry Bridge flea market can be seen as a form of resistance to this polarization, a way of the vernacular memory embodiment in the public space of Tbilisi, and a place for nostalgic experience for the locals and tourists. I have argued that manifestations of vernacular memories, as well as nostalgia, help to revise relations with the past on personal and political levels, to overcome traumatic feelings and make the public sphere more agonistic.

\section{Conflicts and Overlaps between Official Memory and Vernacular Memory in Georgia}

As already mentioned, the official memory of the recent communist period was altered: on the one hand, this alteration took place in order to erase memories of the Soviet Union as a crucial chapter in the history of Georgia and on the other hand, to reproduce the demonized image of that period by focusing mainly on violence and victims of the regime.

During the Rose Revolution and few years after it, Georgian media supported the opposition and shared clearly anti-Russian and anti-Soviet ideas. However later, they started to present more broad coverage of political positions, trying to keep neutrality between pro-Western and pro-Russian views. Printed media is quite diverse in Georgia, and their viewpoint varies from one newspaper to another, as there are communist, ultra-nationalist, radical and neutral newspapers (Kokashvili 2005). However, also there is a share of Russian channels on Georgian television and a part of the population is still watching these programs receiving the Russian propaganda from them (Georgia's Television Landscape 2012). Pro-Soviet ideas are also translated by members of the so-called "Red Intelligentsia" - Georgian actors, writers, and 
moviemakers whose artistic success happened during the Soviet rule. They long for come back to olden times or to recreate the same conditions to return their fame (Chedia 2014). Sometimes their manifestations of the desire to reestablish good relations with Russia go beyond personal ambitions and nostalgia, becoming a political act. Therefore, they also have some amount of coverage in the media.

Although media is more or less diverse in political standpoints, the educational domain in Georgia - which unlike media is controlled by the government has a very strict anti-Russian and anti-Soviet position. Thus, history school books provide a framework about the resistance of Georgians against Russian colonial power and include a chapter on "Georgian occupation" for ninth graders, while students of 12 th grade are requested to write an essay on this topic (Veselý 2008).

In the National Museum of Georgia, there is an autonomous department called The Museum of Soviet Occupation. Although it is considered as an autonomous part, this museum consists of only two rooms in the building of the National Museum where different historical eras of Georgia have been presented through exhibiting domestic items, traditional clothes, weapons, jewelry, books, and documents.

The Museum of Soviet Occupation focuses on the cruelty of the communist regime. Here, one can find official documents and photographs that tell about the horrors of Stalin's repressions: human losses and anti-Soviet riots, unjust arrests, deportations, dekulakization ${ }^{1}$, and dechurching ${ }^{2}$. In addition, there are photographs, personal letters, and pages from diaries of repressed Georgian aristocracy that represent the "lost pride of Georgian nation" who were repressed or executed by the Reds at the beginning of the occupation. The chronicle of arrests, laws, and riots that have been taking place throughout more than 70 years of the Soviet regime in Georgia is printed on black stands. Some of them also have a photo or video evidence, which is also available for the visitors. On the second store of the hall, there are photocopies of letters and reports that display the formal communication among the officials and pleas from citizens to the authorities written in Georgian and Russian languages.

While all of these vile things actually happened, the museum seems to be one sided, as it does not allude to the accomplishments that took place in

1 An appropriation of wealthy peasants' property that happened in the USSR in 1929-1932 under Stalin's reign. Dekulakization is considered as political repression, as people were not only deprived of their property but also, in some cases, arrested, deported, or executed (Warner 2017).

2 The process of the coercive banning of the church as an institution, as well as the destruction of church buildings (Freeze 2015). 
Georgia under the Soviet regime, namely, the major developments in the field of science and industrialization.

The official memory narrative of Georgia also uses the crimes of the communist regime to create anti-Russian propaganda. In line with its propagandistic purposes, the first room of the Museum of the Soviet Occupation displays a video from recent news reports. The video is projected on the wall, showing bombings in Abkhazia and South Ossetia and civilian casualties of that war, as well as anti-Russian and anti-Putin demonstrations all over the country. This is how modern Russian politics is represented as a continuation of the Soviet violent regime in the museum's space. The framing of the video illustrates how official memory serves the interests of the current government, which intends to reduce Russia's influence in Georgia's internal affairs.

The museum is designed as a prison: gray concrete walls, metallic construction, and even a few doors from prisons' cells are exhibited there framing the central passage as if you are in a real prison corridor. Nevertheless, this design demonstrates the attempt of the curators to present the communist period as the darkest era in Georgia's recent history, although it might not be now perceived in that negative light by all Georgians. For instance, respondents in a survey that dealt with public opinion on foreign affairs refer to the Soviet past as the most stable and wealthy period for Georgian citizens, although they admit that human rights were violated in that time (Summary of Focus Group Finding 2017). The exhibition additionally excludes the portrayal of Soviet everyday life that embodies the unique recent past of the country. The fact that the Soviet lifestyle is completely overlooked in this exhibition is not without significance. In my view, a balanced treatment of this aspect would inform the visitors about contemporary Georgia perhaps more than the ancient folkloric artifacts displayed with generosity.

Excluding neutral and positive aspects from the commemoration of the Soviet past neglects the background of people's and institutions' history. This oblivion deprives them of finding their place in the new order of things. All this not only expels materializations of that forgotten or blackened past to the streets but also creates a split between groups of people preventing the equality and unity in the Georgian contemporary society. While the political sphere of the USSR is considered as horrendous and it is illegal to commemorate it, "non-political" spheres of Soviet life, such as art, scientific development, and cultural traditions, are considered as "unworthy of remembering". These "unworthy memories" are actually not forgotten facts but rather lost "between memory and representation", as many people share these memories and may 
remember them even better than those being officially represented (Vukov 2008).

According to Vukov (2008), the reasons for this "silence" could vary from psychological to political. Certain events could be omitted from commemoration even if they are remembered. Sometimes those things that are "unmemorable" or "unworthy of remembrance" are very traumatic events that the society tries to wrap in silence in order not to be retraumatized and to maintain the feeling of prosperity in the current moment. Memories can also be considered as "unworthy" if they are not relevant to the official narrative about the past or as Vukov $(2008,313)$ has written: "worthiness of certain events (and the 'unworthiness' of others) serves to legitimize the logic of hiding certain remembered things from view, and is susceptible to such legitimation due to its highly selective and discriminative character", which makes not possible to create a coherent description of the Soviet era embracing all sides of the communist life.

In modern Georgia, this binary model has been persevered till now as it helps to maintain the new identity of Georgians This may explain why one cannot find any Soviet art in the National Art Museum in Tbilisi. One would not find works of art from the Soviet period, and there is no section dedicated to fashion, industry, and lifestyle between the 1920s and 1990s in any museum in Tbilisi The reason for this neglect is not because all that was depicted and produced during that era were marked by Soviet propaganda at its core but rather because they were not considered "worthy" of remembrance.

Nevertheless, the official and the vernacular memories are not always in contradiction. The official memory may sometimes represent the vernacular memory or they can partially overlap. A very interesting and revealing case illustrating this overlapping of two types of public memory is the Joseph Stalin Museum in Gori, Georgia ${ }^{3}$. The museum was established in 1956 to commemorate Stalin's achievements. At that time, the museum was an example of "official memory". A few years after, it should have been closed according to the legislation against "the cult of Stalin" enacted by Nikita Khrushchev, but massive riots occurred to protect the museum. Today, the museum is still functioning, although its existence is not legal (at least according to the law of Georgia). Thus, in this case, the memory of Stalin can be classified as "official" - as it is institutionalized in form of a state museum - but as long as this museum exists only due to the will of people, it could be considered as "vernacular" as well. This "hybrid" museum is an exclusion - a concession to people's desires and a way to make money from selling tickets.

3 The museum is located in Gori as it is Stalin's hometown. 
However, in Tbilisi, there is a vernacular manifestation of the collective memory in the public space - the Dry Bridge flea market.

\section{The Dry Bridge: a Flea Market and a Vernacular Memorial for the Soviet Past}

In this paper, I approach the Dry Bridge Flea Market seen as a 'vernacular memorial' or a 'lieu de memoire' that crosses the limits of a trading place and becomes a materialization of the Soviet memory in Tbilisi' public sphere. Pierre Nora (1989) had suggested this term, which in translation means 'site of memory', to describe the place which holds memories of a certain epoch or event, when the 'environment of memory' fades. Although Nora posits that, 'lieux de memoire' are established on the institutional level, I argue that 'vernacular memorials' should also be defined as sites of memory.

The Dry Bridge market occupies a vast territory and could be divided into few parts: the first one is a market of newly made paintings and souvenirs. Near it, vendors with artifacts found their place even if there is a separated department with antiques that have around 100 years old or more. However, this paper focuses exclusively on the artifacts from the Soviet period that are displayed at the Dry Bridge flea market in Tbilisi. Of course, this division is not precise as even in this so-called 'Soviet' part there are a lot of objects from different époques and places but particularly in that part of the market most of the goods represent the Soviet past creating this nostalgic communist atmosphere.

At the Dry Bridge flea market, there are a lot of ideological items such as the portraits of Lenin and Stalin made using different artistic techniques, busts of political leaders, flags, and banners of Komsomol ${ }^{4}$ or a banner given as a prize to the winner of the All-Union Socialist Competition. They frame the entire flea market bringing to it the communist atmosphere. Firstly, it is very important for the place itself as it frames the objects of the daily life in the same way the ideology used to frame it in the past. In addition to that, I consider it a reaction to the decommunization, as by being excluded from public sphere they became ghettoized at the flea market. Surprisingly during my research at the Dry Bridge, no potential client was recorded buying items that materialize the Soviet ideology. Some people were excited to see these propagandistic communist things: they called the attention of their friends and family members, who discussed them but never considered buying it.

4 All-Union Leninist Young Communist League. 
This flea market can be regarded as a "vernacular memorial" because it possesses similar characteristics. Some researchers interpret vernacular memorials in the context of a death, calamity or catastrophe (Collins and Opie 2011). Even if The Dry Bridge flea market is not a typical example of a vernacular memorial (it does not commemorate something necessarily traumatic), but it also commemorates a loss. Also, some visitors perceive it as a vernacular museum of the Soviet Georgian past:

"I think it is just a nice place to walk and to see the history of Georgia from the beginning of the twenties century till 90s. Just like in the museum!" - T. from Russia shares her motivation for coming.

"We came here because it is very interesting all these images of Stalin, vinyl, Communist stuff (...) We have flea markets in Italy, but it is very fascinating to see this side of Georgian history" - tell Italian tourists who accidentally found out about the existence of the market.

The Dry Bridge flea market is a vernacular memorial that provides an opportunity to reflect on a bygone period and lost ideology, which evokes interest among foreign tourists. The flea market is not just a secondhand trading point - it is an important urban site for locals and tourists that attracts hundreds of people daily. The Dry Bridge is important for locals, and some of them see it as a unique and an important place for Tbilisi:

"This market should not disappear. (...) This market exists not only for tourists but also for collectors and people who like vintage stuff - they buy and sell here. It is a very cool place. (...) It has its importance to the locals, as when in the 1990s it was not possible to buy anything as nothing was imported in Georgia, we used to come here to buy aluminum pots, Yugoslavian crystal tableware and so on. People still remember it", T., a local visitor, explains the importance of the market to Tbilisians.

Tbilisi's flea market not only conserves and exhibits artifacts that come from another era - just like a museum or an official lieu de memoire does - but also creates an "agonistic public space". Mouffe (2007) coined this term to describe a public sphere in which emotions and various discourses oppose hegemony. Mouffe wrote about democracy and power, but in this case, the "hegemony" of the official memory should also be considered as a political issue. The Dry Bridge market, being a vernacular memorial, brings to light items, photographs, and documents that are banned from Tbilisi's public sphere, and this confrontation with the official historical narrative makes the public space more "agonistic". 
The agonism in the public space provides an opportunity for resistance to a new tempo of life and the demands of the capitalistic society, to which many people cannot adjust. The Dry Bridge flea market became, to a certain extent, a way to adapt and survive in the new economic order (Pachenkov and Voronkova 2006). The market appeared in Tbilisi after the Soviet Union collapsed and when people were forced to earn money by selling their personal belongings due to unemployment at that time. After a while, the financial situation stabilized, and those vendors who remained at the Dry Bridge seem to be there as this environment was very comfortable for them: here, they do not need to find a place for themselves in the modern capitalistic society of Georgia (Bloshyniy Rynok na Sukhom Mostu 2009).

"I came here in 1997 and since then I am every day at the Bridge. It is not a question if I like it or not, or if I could have another job. I belong here: people know me and I am respected by other sellers. Where else I would go if my life is here?", says A., a vendor.

The behavioral practices of the sellers, the free time they spend playing backgammon, or the personal dialogs they have with potential buyers, even if the latter are not interested in purchasing, may be considered as a form of resistance to the capitalist society and its speed. The vendors do not integrate into it and tend to create an environment that preserves a lifestyle that is neither communist nor capitalist.

"I started with selling my own stuff, I am getting older and I do not all these things anymore. Also at those times, I needed money, so I started trading here. Now people bring stuff to me, sometimes I find things by myself... It is a very dynamic lifestyle. It is not an easy one, indeed, but I enjoy it, as I am my own boss and there are always interesting people around me", tells M., a trader.

Therefore, people at the market reproduce behavioral patterns of two different anti-capitalist archetypes: flaneurs and squatters. Vendors are more resemblant to squatters who occupy the public space and live there almost like a commune refusing to obey the capitalistic principles of life and also squatting the items abandoned or unneeded by owners and making their livings from them. They become time and space squatters, and as it is not possible to occupy past time, they appropriate the materializations of that era. Visitors of this flea market could be representatives of flaneurism.

Flaneurism according to Buck-Morss (1986) is a "consumerist mode of being in the world". In this sense, spending time at the flea market corresponds to the concept of flaneurism as the interaction with the surroundings also involves trading relations even if one follows the rule of flaneur: "look but do not touch". 
However, if the flaneur is interested in modernity itself, the flea market visitor observes the relationship between the current moment and the past.

"Actually, we did not come here to buy something - just because of curiosity. We read online about that place and came. It is just amazing to stroll here and see all these familiar items and nostalgize about the old days", says O., a tourist from Ukraine.

Thus, he or she strolls not only on the squatted streets but simultaneously in his or her memories, putting a nostalgic gaze to the items on sale that belong to both of these time periods. Sometimes, it seems that time did "stop" in the early 1990s. This demeanor, in my view, could also be considered a lieu de memoire, although it is intangible and could be interpreted through the lens of the "resistance to capitalism". However, capitalism is not the only thing that people from the post-Soviet territory - both vendors and buyers - try to resist with the help of nostalgia.

\section{Memory for Sale: Nostalgia As Commodity}

For many people, the Dry Bridge is a place of commerce rather than a vernacular memorial.

The Dry Bridge flea market is a place where one can find a huge variety of cutlery and crockery from the Soviet times. Several of them - such as porcelain dinnerware or a set of crystal glasses - were the "object of desire" for many Soviet families. Unlike the majority of other goods that attract mostly tourists, these domestic artifacts are also hunted by locals.

"Of course I do not come here very often. I usually prefer to buy in the shops. But now I need glasses and I wanted something fancier (...) And I always like this kind: colored class and engravings .... My aunt used to have similar long time ago. (...) and the price is nice. You know, sellers would tell you a crazy price, but we, locals, can make a good bargain", says N., a Tbilisian woman in her late 50s.

I relate this fascination with domestic items to the fact that once they used to symbolize wealth and exquisiteness. Today, Georgians are given an opportunity to buy eventually the desired set of dinnerware as they are affordable and do not need to machinate to obtain it. Thus, the Dry Bridge flea market becomes a source of artifacts once desired, which have now become affordable.

It is very important to notice that in the former USSR, some groups of products were unavailable to the citizens not because of their high price as it happens now in the capitalistic system - but because to buy them a person needed to have had access to stores for Communist Party workers or to know someone who was keeping these products "under the counter". After 
the dissolution of the Soviet Union, some goods were still unavailable because of their price. Currently, we can easily observe that having an opportunity to get different items, some people prefer to buy those that were desired by them in the Soviet times. I would say that this is an attempt to restore the broken home and return to a certain security and stability that is associated with the Communist period. Thus, not only nostalgia becomes a motivation to buy an item but also a purchase fulfills old longings and creates a connection between now and then.

In addition, the Dry Bridge flea market is a source for those who deal with esthetics of the past, creating movies and pictures inspired by the Soviet times. For them, it is an endless source of inspiration and requisite:

"I came here because we are filming a short movie with my friends and we need a lamp for a setup and everyone knows that if you need something old and beautiful you should come here. It is a paradise for artists who work with historical movies", tells L., a Georgian art student.

Others are looking for vintage accessories to use in the creation of their outfits: "Here I am searching accessories like badges and clock to mix with new clothes. No, I do not consider myself nostalgic about the USSR, I just like the aesthetics of those times. They look nice and ironic", tells Y., a tourist from Ukraine in his early 20 s.

It is important to look at reasons of fascination with vintage items. Recently, a return to the so-called "old school" looks and exploitation of recent past on the TV became a popular tendency in mass culture (Kellner 2003). This tendency can be explained by nostalgic feelings. Commodification of nostalgia is done through re-exoticization of the past: familiar and even cherished items become a part of commerce as they are sold as a "strangeness of a world that no longer exists" (Cooke 2005). This fascination with strangeness and carnivalesque visual culture (Bartmanski 2011, 217). of using symbols and items of the communist times helps to reexamine one's relations with the past and "to develop a playful, almost flirtatious relation with symbols of a jettisoned reality that would never have been possible in public when the rules of that reality were still enforced" (Cooke 2005). Nevertheless, commodification of memory and profit it brings to sellers and post-modernist fascination with the past among younger generations do not cover all the modalities of nostalgia that exist at the Dry Bridge. 


\section{Childhood Nostalgia at the Dry Bridge Flea Market}

Nostalgia, as defined by Boym (2007, xvii), is "a longing for a home that no longer exists or has never existed [...], a sentiment of loss and displacement, [...] a romance with one's own fantasy". In other words, nostalgia could be described as a desire to come back to the past period of time or to some place, although the memory of this site or time is idealized and this place may not exist anymore or could never have existed.

As nostalgia stands in-between the individual and collective past, it is considered as a type of collective memory (Boym 2007, 8-9). However, there is a tendency to interpret nostalgia as the least trustworthy type of memory, which is opposed to history (Cook 2004, 3). This reasoning deals with absolute forms of history and nostalgia that seldom exist. History may operate with "sentimentalized expressions of regret", whereas nostalgia is based on recollections that have not been altered to serve the political ideology. Such recollections may be more reliable as they are much more diverse in their representations. Additionally, they are shared by people who actually lived in the period, which is an object of their nostalgia. As Pickering and Keightley (2006) argued, there are different "modalities of nostalgia", and this part of the paper explores in which "modalities" nostalgia exists at the flea market of Tbilisi.

Nostalgia is described, among other definitions, as "a yearning for a different time - the time of our childhood, the slower rhythms of our dreams. In a broader sense, nostalgia is a rebellion against the modern idea of time, the time of history and progress" (Boym 2007, 8). As observed within my research, for a sufficient number of the Dry Bridge flea market buyers, nostalgia is strongly connected to their childhood: they buy and scrutinize playthings, such as toy cars and railways and the small abacuses, they had or wanted to have as children. Moreover, nostalgic feelings could be shared also by teenagers. In this case, we are not talking about nostalgia orientated toward "golden" times of the USSR but rather to the beginning of the 2000s. During my fieldwork at the Dry Bridge, I was observing how male teenagers were gazing admiringly at a toy car that reminded them of the one they had as children. A similar longing for the past has been revealed by two men in early 40 s, who had the same reactions and discussions about another toy car.

This 'childhood oriented' modality of nostalgia creates a false impression that nostalgia is retrospective and utopian and deals only with dreams and fantasies. In addition, there is a common belief that nostalgia is an "unhealthy" and "anti-modern" type of memory, which orientates one toward the past, rather than to be present in the moment. On the contrary, even though nostalgia 


\section{Elisabeth Kovtiak, A Bridge to the Past: Public Memory and Nostalgia for the \\ Communist Times in Modern Georgia}

uses recollections and materialized memories of a certain period as its main source, it is very modern and constantly changes, adapting to the emotional needs of people in the modernity.

Nostalgia is similar to childhood memories as the latter might be uncertain and idealized, and nostalgia is a yearning for an idealized version of past (Hirsch 1992). Material objects that remind us of the childhood help to create a better bond to the recollection of the past. This property of objects always had been exploited by industrial production that has a tendency to reproduce vintage toys, packages to attract nostalgic consumers (Moran 2002). Yet, the originals are still valued as such. Therefore, flea markets that sell not just resembling but exactly the same objects prosper. Furthermore, Moran argued that nostalgia is created not only by narrative forms but also by visual images and physical objects. So in this interpretation, one can suggest that flea market exists not only to serve nostalgic moods of people but also to create them.

"It is interesting here! It is amazing how Georgia is so different but things they sell here are just like what my grandmother used to have in her house", tells O. from Ukraine

"Look! We used to have exactly the same painting in the living room when I was younger. I considered buying it but I have to think if I really want it. At least, I am going to take a picture of it to have it as a memory", tells P. from Russia.

For those who are reflectively nostalgic ${ }^{5}$, these objects seem to frame domestic objects of the Soviet everyday life, increasing the feeling of facing the past rather than being a serious interest of those who experience the "reflective" nostalgia. It is very unlikely that someone actually furbishes the apartment exclusively with items from the past times to rebuild the bygone époque or a particular period of life. However, elements that carry this nostalgic emotion can be described as a small bridge to the past that connects to the present, making the latter more stable and real. This can be achieved with the help of an interior detail or a pin, which are items that are extremely popular among younger tourists. It could be a place or even uncontrolled emotional experience that helps to reconnect to the past or with your roots and identity, which can be very helpful for reconsidering the present moment and resisting the increasing pace of the modern life.

5 Boym (2007, 13-14) distinguished between two types of nostalgia: restorative and reflective. As restorative nostalgia aims to bring features of the past epoch to the present and to restore or rebuild the previous order of things, reflective nostalgia concentrates on the feeling of "longing" itself. Reflective "types" deal with the past in an ironical way and do not actually articulate the desire to go back in time or to restore a bygone era in the present. It is my argument that the nostalgia of Tbilisi's flea market is closer to the "reflective" type, but of course, there are elements of "restoration" as the phenomenon of nostalgia is very complex and cannot be limited to a simplified category. 
Childhood nostalgia can be a reaction to changes in the economy and society and can have a soothing effect on the anxiety caused by these changes. Thus, reconnecting to familiar images could be a cure to the feeling of instability in the modern age (Moran 2002, 173). In this light, childhood nostalgia is similar to post-Communist nostalgia as they both offer coziness of a bygone stable period in which a parental figure was providing stability and comfort. The parental figure to which I am referring here is present in both "models" of nostalgia as an actual parent (especially if we talk about childhood and a political leader such as Stalin in the case of the communist nostalgia).

\section{Nostalgia for the Big Motherland}

Nostalgia for the Soviet Union is very close, in its core, to the original understanding of nostalgia as "the desire for return to one's native land" (Hofer 1934). The loss that post-Soviet nostalgia tries to overcome is the loss of "the big motherland".

"We used to live normally together, and then these politicians ruined everything. Georgia had to be the main resort of the Soviet Union! We were the most loved and the jolliest people. Everyone liked us - we were welcomed everywhere and we could go anywhere", tells K., a vendor at the Dry Bridge.

"Half of the world used to be our: people were coming to us and we were traveling everywhere in the USSR. Now it is harder and more expensive ... For example, me ... where I would go?”, says I.

"We used to be one country, best friends, and then this Saakashvili started to tell them that we are invaders. That is insane, I have a cousin here and we have no problems", says V. from Russia.

Fascination with the idea of the big motherland is still present. In many recorded situations at the Dry Bridge flea market, vendors suggested the

6 The concept of the big motherland has to be explained through a description of its two components. The Soviet Union propaganda, especially at the times of the Second World War, used the female images and the word "Rodina" (the motherland) to address the soldiers and civilians. The most famous patriotic slogans of those times were "Rodina mat' zoviot!" (The motherland is calling you!) and " $Z a$ Rodinu! Za Stalina!” (For the motherland! For Stalin!). This tradition derives from the concept of "the Mother Russia”, which was widely used in the Russian Empire, although in the first Soviet years, the idea of the "proletarian nomadism" had been promoted. Yet, during the Stalin's time, the discourse of the "motherland" was resurrected. The word motherland addresses emotions and patriotic feelings of people and can be opposed to the "Fatherland" (Otechestvo) that had been used mostly in the political discourse. In addition, the big motherland in the Russian language differs from a small motherland, brought into usage in the Khrushchev's times, which refers to one's native town or village or could be also used to call one of 15 constituent republics of the USSR. Some scholars claim that the dissolution of the USSR was a consequence of the growing popularity of the "small motherland" (Sandomirskaya 2001). Hence, after the dissolution of the Soviet Union, which represented the big motherland, the identification with it was no longer possible, and Georgians had to reconstruct their national identity based on the pre-Soviet history. 
purchase of items that either were common for the whole Soviet "world" or derived from a visitor's home country. There is a vast group of artifacts displayed for sale at the Dry Bridge consisting of porcelain figurines. Some of them depict representatives of the USSR's nationalities dressed in their traditional costumes. These figurines used to be a very popular type of souvenir, usually brought from travels to other Soviet Republics, especially to the remote ones. Other figurines represent the common cultural background of all Soviet Republics that was created on the basis of the hegemonic Russian culture: famous writers, ballerinas, and fairytale characters were known and loved by many since the Russian culture was used as an imperialist glue to annihilate differences between nations in the attempt to create the so-called "the Soviet identity". These figurines could be found anywhere in the USSR. They found their place at the nostalgic flea market as they represent the lost unity, brotherhood, and mobility inside of the USSR, which are missed by Georgians and people of other post-Soviet nations. In the majority of cases, people were excited to find something related to their countries and personal experience at the Tbilisi's flea market. All this gives me a reason to claim that nostalgia, in this case, works also as a resistance to today's disunity of the Soviet bloc and a mental attempt to feel the unity and safety that communist era gave to people.

The motherland is not a real place but a meta-trope through which a collective identity is built. "Being a fictitious denoter, a product of cultural construction, it is primarily a 'plot'. The motherland cannot be referentially or deictically specified, but it can be told", so it is a narrative rather than a place (Sandomirskaya 2001, 11-13). Thus, talking to former countrymates, taking with them in the lingua franca of the USSR, being close to artifacts that symbolize the vanished motherland, and building a visual narrative about the USSR using material objects is a way to reconnect with a feeling of belonging to a bigger motherland as it gives a feeling of security and belonging. This does not mean necessarily that they actually want to go back in time. However, going back in time is also impossible as it is neither time nor place but rather a feeling for which one can be nostalgic.

As the Soviet Union highly supported the idea of unity and intercultural friendship on the ideological level, people felt that they belonged to an enormous community of people living in a vast territory. After the USSR collapsed, people found themselves locked in small countries, separated not only from their "comrades" but also from family members. In the case of many post-Soviet countries, and Georgia in particular, this metaphor of nostalgia being a longing to return to the "broken home, which no longer exists" is 
less figurative, as their "home", and by this, I mean that "the motherland" was actually (and literally) "broken", as Georgia suffered a lot after the fall of communism.

\section{Conclusion}

The current discourse on the new democratic Georgia is built upon ancient history and myths as a base for a new identity. Part of this "new Georgian identity" formation consists of the condemnation and demonization of the Soviet period, blamed for the displacement of Georgians' public memory and religion. This strategy inspired the population and supported positive social and political changes. Even after Saakashvili's resignation, these ideas are still alive and there is an attempt to erase that period of time to achieve unity among citizens and reinforce "new, Western values". Nevertheless, the new official memory regime uses the same weapon that the communist preferred the weapon of organized forgetting. However, an identity built on forgetting is a weak one and can be easily manipulated, as "societies that agree and acknowledge their past can be more successful at democracy" (Kenney 2006).

In Georgia, the vernacular memory of the Soviet past creates opposition to the official narrative that serves the ideological purposes of the current government. As people share esteemed memories about the Soviet period, both on the individual and the collective levels, they are in need of its materialization. Hence, the vernacular memorials appear to reveal versions of public memory, which differ from the "official memory". The Dry Bridge flea market is also a vernacular memorial, which is important not only as a popular tourist attraction but also because it creates an agonism in the ways of articulation of public memory in Tbilisi's public space. However, this place goes beyond the limits of a memorial, as people who come there to buy something or just to look at old items share a bittersweet feeling of nostalgia. This flea market with its nostalgic spirit, supported by materializations of the memory of the communist past, helps people resist the official narrative that supports separations of nations in the former Soviet bloc. The aim of this paper was to show that nostalgia should not be considered as "unhealthy" or "retrospective" as it helps people to adapt to modernity and develop by considering more than one hegemonic version of their past. Thus, both vernacular memory and nostalgia create a way for generations to find their place in the modern age through recourse to the past.

Vernacular memorials have a nostalgic background. Nostalgia becomes a unifying power that helps Georgians and other representatives of the former USSR to reconcile with the past and to create a more agonistic public sphere 


\section{Elisabeth Kovtiak, A Bridge to the Past: Public Memory and Nostalgia for the}

Communist Times in Modern Georgia

that will be more exclusive. Different modalities exist as people search for different remedies. Commodification of memory, or consumerist nostalgia, helps to reestablish, perhaps in a more ironic way, relations with the past. Childhood searches carelessness and reconciliation with one's personal past through collective memory and common things. Nostalgia for the big motherland is a way to come back to a more friendly world, to feel more included, and to overcome the trauma of disintegration of the USSR and wars and instabilities that happened after it. All these modes of vernacular memory create a more agonistic negotiation of the past in the public sphere, which helps to build more balanced social and political environment.

\section{References}

Asavei, Maria-Alina. 2016. "Nicolae Ceauşescu: Between Vernacular Memory and Nostalgia." Twentieth Century Communism 11: 27-42.

Bartmanski, Dominik. 2011. "Successful Icons of Failed Time: Rethinking Post-Communist Nostalgia.” Acta sociologica 54 (3): 213-231.

"Bloshyniy Rynok na Sukhom Mostu [The Dry Bridge Flea Market]." 2009. Art project 'Flea Martket.' February 4. http://www.bloxa.ru/articles/georgia/tbilisi/suhoi most/.

Bodnar, John E. 1992. Remaking America: Public Memory, Commemoration, and Patriotism in the Twentieth Century. Princeton: Princeton University Press.

Boym, Svetlana. 2007. "Nostalgia and Its Discontents." Hedgehog Review 9 (2): 7.

Buck-Morss, Susan. 1986. "The flaneur, the Sandwichman and the Whore: the Politics of Loitering." New German Critique 39: 99-140.

Collins, Catherine Ann, and Alexandra Opie. 2010. "When Places Have Agency: Roadside Shrines as Trau Mascapes." Continuum 24 (1): 107-118.

Cook, Pam. 2004. Screening the Past: Memory and Nostalgia in Cinema. New York: Routledge.

Cooke, Paul. 2005. Representing East Germany since Unification: From Colonization to Nostalgia. New York: Berg Publishers.

Fairbanks, Charles H. 2004. “Georgia’s Rose Revolution.” Journal of Democracy 15 (2): 110124.

Freeze, Gregory L. 2015. "From Dechristianization to Laicization: State, Church, and Believers in Russia." Canadian Slavonic Papers 57 (1-2): 6-34.

Gachechiladze, Revaz. 1997. "National Idea, State-Building and Boundaries in the Post-Soviet Space (the case of Georgia)." GeoJournal 43 (1): 51-60.

Hirsch, Alan R. 1992. "Nostalgia: a Neuropsychiatric Understanding.” ACR North American Advances: 390-395.

Hofer, Johannes. 1934. “1688. Medical Dissertation on Nostalgia.” Trans. Carolyn K. Anspach. Bulletin of the History of Medicine 2: 376-91.

Houdek, Matthew, and Kendall R. Phillips. 2017. "Public Memory." Oxford Research Encyclopedia of Communication. http://communication.oxfordre.com/view/10.1093/acrefore/9780190228613.001.0001/acrefo re-9780190228613-e-181?rskey=untdbH\&result=1. 


\section{Journal of Nationalism, Memory \& Language Politics 12(1)}

Jakopovich, Dan. 2007. “The 2003 'Rose Revolution' in Georgia: A Case Study in High Politics and Rank-and-File Execution." Debatte 15 (2): 211-220.

Kellner, Douglas. 2003. Media Culture: Cultural Studies, Identity and Politics between the Modern and the Post-Modern. London: Routledge.

Kenney, Padraic. 2006. The Burdens of Freedom: Eastern Europe since 1989. London: Zed Books.

Kokashvili, Marina. 2005. "The Role of the Media in Georgia's Transition to Democracy." In From Revolution to Reform: Georgia's Struggle with Democratic Institution Building and Security Sector Reform, edited by Philipp H. Fluri and Eden Cole, 209-29. Vienna: National Defense Academy; Geneva: Centre for Democratic Control of the Armed Forces.

Kuzio, Taras. 2002. "History, Memory and Nation Building in the Post-Soviet Colonial Space.” Nationalities Papers 30 (2): 241-264.

Moran, Joe. 2002. "Childhood and Nostalgia in Contemporary Culture." European Journal of Cultural Studies 5 (2): 155-173.

Mouffe, Chantal. 2007. "Artistic Activism and Agonistic Spaces." Art \& Research 1 (2): 1-5.

Nora, Pierre. 1989. “Between Memory and History: Les Lieux de Mémoire.” Representations: 7-24.

Pachenkov, Oleg, and Lilia Voronkova. 2009. "New Old Identities and Nostalgias for Socialism at St. Petersburg and Berlin Flea Markets." In Changing Economies and Changing Identities in Postsocialist Eastern Europe, edited by Ingo W. Schroder and Asta Vonderau, 191-216. Berlin: Lit.

Parliament of Georgia. 2011. Freedom Charter, Law of Georgia, 4717-I冈. Tbilisi.

Pickering, Michael, and Emily Keightley. 2006. “The Modalities of Nostalgia.” Current Sociology 54 (6): 919-941.

Shafir, Michael. 2006. "Memory and History in Postcommunism: Preliminary Theoretical Remarks." Sfera Politicii 120-121: 122.

Sandomirskaya, Irina. 2001. Kniga o Rodine. Opyt analiza diskursivnykh praktik [Book about Motherland. Experience in the Analysis of Discursive Practices]. München: Institut für Slavische Philologie.

Shevel, Oxana. 2016. “The Battle for Historical Memory in Postrevolutionary Ukraine.” Current History 115 (783): 258-263.

Stefes, Christoph. 2006. Understanding Post-Soviet Transitions: Corruption, Collusion and Clientelism. New York: Springer.

"Summary of Focus Group Findings: Public Opinion on Foreign Affairs." 2017. NDI Georgia. June. https://www.ndi.org/sites/default/files/NDI May\%202017 Focus\%20Groups\%20 Report_English_final.pdf.

“The Red Intelligentsia of Georgia Strikes Back." 2013. Eastbook. May 1. http://www.eastbook.eu/en/2013/05/01/the-red-intelligentsia-of- georgia-strikes-back/.

Tsygankov, Andrei P., and Matthew Tarver-Wahlquist. 2009. "Duelling Honors: Power, Identity and the Russia-Georgia Divide." Foreign Policy Analysis 5 (4): 307-326.

Yurchak, Alexei. 2013. Everything was Forever, Until It was No More: The Last Soviet Generation. Princeton: Princeton University Press. 
Veselý, Luboš, ed. 2008. Contemporary History Textbooks in the South Caucasus. Prague: Association for International Affairs (AMO).

Vukov, Nikolai. 2008. “The 'Unmemorable' and the 'Unforgettable': 'Museumizing' the Socialist Past in Post-1989 Bulgaria." In Past for the Eyes: East European Representations of Communism in Cinema and Museums after 1989, edited by Oksana Sarkisova and Peter Apor, 307-334. Budapest: Central European University Press.

Warner, Geoffrey. 2016. The Oxford Handbook of European History, 1914-1945. Oxford: Oxford University Press. 